\title{
Nitric oxide induced alleviation of toxic effects of short term and long term Cd stress on growth, oxidative metabolism and $\mathrm{Cd}$ accumulation in Chickpea
}

\section{Anita Kumari, Sunita Sheokand and Kumari Swaraj}

Department of Botany and Plant Physiology, CCS Haryana Agricultural University, Hisar 125004, India

*Corresponding author: sunitasheokand@hotmail.com

Received: 27 June 2010; Accepted: 04 February 2011

\begin{abstract}
The present study investigates the effect of long and short term Cd stress in chickpea plants and evaluates the protective effect of exogenous nitric oxide (NO) supplementation using sodium nitroprusside (SNP). Cadmium treatments were given before sowing (long term stress) and thirty days after germination (short term stress). Sodium nitroprusside was given as foliar spray 30 days after germination to both long and short term $\mathrm{Cd}$ treated plants. Cadmium adversely affected the membranes as was evident from increased electrolyte leakage and lipid peroxidation levels. Sodium nitroprusside treatments decreased ion leakage and lipid peroxidation levels significantly. Short term Cd stress resulted in a higher induction of the catalase, peroxidase, ascorbate peroxidase, glutathione reductase and superoxide dismutase as compared to long term $\mathrm{Cd}$ stress. Nitric oxide showed its positive effect by further increasing the activities of antioxidant enzymes. Cadmium stress also altered the level of antioxidant metabolites by reducing the ascorbate redox ratio (ASC/DHA) and glutathione redox ratio (GSH/GSSG). Sodium nitroprusside treatments increased the redox ratios. Cadmium also adversely affected the seed yield and a greater decline was observed with long term $\mathrm{Cd}$ stress as compared to short term $\mathrm{Cd}$ stress. Nitric oxide had a positive effect on seed yield and $\mathrm{Cd}$ accumulation. The study concludes that an exogenous supply of NO protects chickpea plants from Cd toxicity.
\end{abstract}

Key words: Antioxidant enzymes; lipid peroxidation; membrane injury; sodium nitroprusside.

Abbreviations: APX, ascorbate peroxidase; CAT, catalase; GR, glutathione reductase; malondialdehyde (MDA); POX, peroxidase; SOD, superoxide dismutase.

\section{INTRODUCTION}

Cadmium (Cd) pollution is a global problem and near about $3 \times 10^{3}$ tons of $\mathrm{Cd}$ enter the environment annually (Sanita di Toppi and Gabbrielli, 1999). In plants cadmium toxicity can cause reduction in growth (Kopyra and Gwozdz, 2003). At cellular level $\mathrm{Cd}$ acts as a pro-oxidant and induces oxidative stress by generation of reactive oxygen species
(ROS) (Kopyra et al., 2006) as evidenced by enhanced lipid peroxidation, $\mathrm{H}_{2} \mathrm{O}_{2}$ generation and ion leakage (Dixit et al., 2001; Sandalio et al., 2001; Milone et al., 2003; RomeroPuertas et al., 2004; Smeets et al., 2005; Rodriguez-Serrano et al., 2006). It also alters the level of antioxidant enzymes (Olmos et al., 2003; Rodriguez-Serrano et al., 2006) as a defense mechanism against $\mathrm{Cd}$ induced ROS production $\left(\mathrm{H}_{2} \mathrm{O}_{2}, \mathrm{O}_{2}^{-}\right.$and $\left.\mathrm{OH}^{-}\right)$. 
The balance between free radical generation and free radical scavengers determines the survival of the system under stress conditions. Increasing the concentration of free radical scavengers by exogenous application could help in detoxification of stress-induced free radical production (Wang et al., 2004; Wang and Yang, 2005; Zhang et al., 2006). In this study, we have used nitric oxide (NO) as an antioxidant compound. Nitric oxide (NO) is a small highly diffusible and ubiquitous bioactive molecule that takes part in many physiological processes in plants. Its chemical properties makes NO a versatile signal that functions through interactions with cellular targets via either redox or additive chemistry (Wendehenne et al., 2004). It is involved in seed germination (Beligni and Lamattina, 2000), growth and development (Desikan et al., 2004), flowering (He et al., 2004), hormonal responses (Zhou et al., 2005), mitochondrial functionality (Zottini et al., 2002) and gravitropism (Hu et al., 2005). Nitric oxide (NO) is itself a reactive oxygen species and its dual behaviour (protective or toxic) depends upon both concentration and the tissue where it acts (Beligni and Lamattina, 1999; Hsu and Kao, 2004). The protective role is based on its ability to regulate the level and toxicity of ROS. Nitric oxide has been suggested to be involved in defense responses to biotic and abiotic stresses (Wendehenne et al., 2004) and appears to be present in most of stress reactions. It has been reported to exert a protective effect in response to drought stress (Mata and Lamattina, 2001), osmotic stress (Wang et al., 2004; Zhao et al., 2008), salt stress (Shi et al., 2007; Li et al., 2008; Sheokand et al., 2008), heavy metal stress (Kopyra and Gwozdz, 2003; Hsu and Kao, 2004; Wang and Yang, 2005; Singh et al., 2008) and oxidative stress (Beligni and Lamattina, 2002).

However, experimental evidence for $\mathrm{NO}$ as a signal molecule for oxidative metabolism under $\mathrm{Cd}$ stress is preliminary. The present work aims at investigating the role of exogenously supplied SNP (NO donor) in alleviating the short term and long term Cd stress in chickpea.

\section{MATERIALS AND METHODS}

The present investigations were carried out on chickpea (HC-3) plants. Seeds were procured from Pulses Section, Department of Plant Breeding, CCS Haryana Agricultural University, Hisar. All biochemicals used during the present investigations were purchased from Sigma Chemical Company (St. Louis, USA), Sisco Research Laboratories Pvt. Ltd., India (SRL) and Aldrich Chemical Company (Germany) and were of highest purity.

Growth culture and treatments: The seeds were raised in polyethylene lined earthen pots containing $5 \mathrm{~kg}$ loamy sand. The seeds were surface sterilized with $80 \%$ ethanol for two min and washed repeatedly with distilled water then inoculated with Rhizobium culture provided by Department of Microbiology, CCS HAU, Hisar. The plants were supplied with equal volume of nitrogen free nutrient solution (Wilson and Reisenauer, 1963) at regular intervals, except for an initial starter dose of combined nitrogen (5 mM NH $\mathrm{NNO}_{3} @ 250 \mathrm{~mL} /$ pot). Cadmium was applied through the rooting medium and given to two sets of plants. In the first set $\mathrm{Cd}$ treatments were given before sowing and termed as long term $\mathrm{Cd}$ stress. In second set $\mathrm{Cd}$ treatments were given after 30 days of germination and termed as short term Cd stress. Nitric oxide donor SNP $(250 \mu \mathrm{M})$ and NO scavenger c-PTIO $(100 \mu \mathrm{M})$ were applied after 30 days of germination through foliar spray. The pots were grouped into the following treatments: 1. Control 2. Control + SNP (250 $\mu \mathrm{M})$ 3. Cd $10 \mathrm{ppm}$ 4. Cd + SNP $(250 \mu \mathrm{M}) 5$. Cd + SNP (250 $\mu \mathrm{M})+\mathrm{C}-\mathrm{PTIO}(100 \mu \mathrm{M})$.

Samplings were done 24 and $72 \mathrm{~h}$ after treatments given 30 days after germination and the following observations were taken.

Membrane injury (MI) and lipid peroxidation: Membrane injury was analyzed according to the method of Zhang et al. (2006). The level of lipid peroxidation in plant tissue was quantified by determination of malondialdehyde (MDA) content, a breakdown product of lipid peroxidation. The concentration of MDA was calculated using the extinction coefficient of $155 \mathrm{mM}^{-1} \mathrm{~L}^{-1} \mathrm{~cm}^{-1}$ as described previously (Sheokand et al., 2008).

$\mathrm{H}_{2} \mathbf{O}_{2}$ content: Plant tissue $(1 \mathrm{~g})$ was ground in $6 \mathrm{~mL}$ of chilled $0.8 \mathrm{~N} \mathrm{HClO}_{4}$ and centrifuged at 10,000 rpm for 30 min. The clear supernatant was decanted and neutralized with $5 \mathrm{M} \mathrm{K}_{2} \mathrm{CO}_{3}$ and again centrifuged at $10000 \mathrm{rpm}$ for 30 min. This supernatant $(200 \mu \mathrm{L})$ was used for $\mathrm{H}_{2} \mathrm{O}_{2}$ estimation and made to $1 \mathrm{~mL}$ with $0.1 \mathrm{M}$ phosphate buffer ( $\mathrm{pH} 7.5$ ) then $2 \mathrm{~mL}$ of $5 \%$ potassium dichromate and glacial acetic acid $(1: 3 \mathrm{v} / \mathrm{v})$ was added to it. The mixture was then heated in boiling water bath for 10 min and cooled. Its absorbance was read at $570 \mathrm{~nm}$ against reagent blank which was without 
sample extract (Sinha, 1972). The quantity of $\mathrm{H}_{2} \mathrm{O}_{2}$ was determined from standard curve prepared similarly with 0 - $100 \mathrm{n} \mathrm{mol} \mathrm{H}_{2} \mathrm{O}_{2}$.

Reactive oxygen species (ROS) content: Reactive oxygen species (ROS) production was measured as described by Able et al. (2003) by monitoring the reduction of XTT (2,3-Bis(2-methoxy-4-nitro-5-sulfophenyl)-2H-tetrazolium5-carboxanilide-inner salt), with some modifications. Leaves $(250 \mathrm{mg})$ were homogenized with $1.5 \mathrm{~mL}$ of $50 \mathrm{mM}$. K-phosphate buffer ( $\mathrm{pH} 7.8$ ) and centrifuged at $5000 \mathrm{rpm}$ for $10 \mathrm{~min}$. The reaction mixture $(1 \mathrm{~mL})$ contained $50 \mathrm{mM}$ K-phosphate buffer (pH 7.8), $400 \mu \mathrm{L}$ supernatant and $500 \mu \mathrm{L}$ of $0.5 \mathrm{mM} \mathrm{XTT}$. The reduction of XTT was determined at 470 $\mathrm{nm}$ for $3 \mathrm{~min}$. Corrections were made for the absorbance of chlorophyll. Production of ROS was calculated by using an extinction coefficient of $2.16 \mathrm{~m}^{-1} \mathrm{~cm}^{-1}$.

Determination of enzyme activity: Cell free extract for various antioxidant enzymes viz, CAT, SOD, APX, DHAR, GR, POX and MDHAR was prepared by macerating $500 \mathrm{mg}$ of leaf tissue in a chilled pestle and mortar in presence of $3.0 \mathrm{~mL}$ of cold extraction buffer (potassium phosphate $\mathrm{pH} 7.8$ ) containing 0.1 mM EDTA, $1 \%$ (w/v) PVP, $0.5 \%$ triton X-100 and 20\% glycerol. The homogenate was centrifuged at $10,000 \times g$ for 15 min at $4^{\circ} \mathrm{C}$. The supernatant was carefully decanted and used as the crude enzyme extract.

Catalase (E.C. 1.11.1.6) and peroxidase (E.C. 1.11.1.7) activity was estimated as described previously (Sheokand et al., 2008). For catalase the reaction mixture in final volume of $3 \mathrm{~mL}$, contained $0.1 \mathrm{M}$ phosphate buffer ( $\mathrm{pH} 7.0$ ), $10 \mathrm{mM}$ $\mathrm{H}_{2} \mathrm{O}_{2}$ and $50 \mu \mathrm{L}$ of cell free extract. Reaction was initiated with the addition of $\mathrm{H}_{2} \mathrm{O}_{2}$ and enzyme activity was determined by following the degradation of $\mathrm{H}_{2} \mathrm{O}_{2}$ at $240 \mathrm{~nm}$ for 2 min. The enzyme activity was calculated using the extinction coefficient value of $39.4 \mathrm{mM}^{-1} \mathrm{~cm}^{-1}$ for $\mathrm{H}_{2} \mathrm{O}_{2}$. One unit of enzyme activity corresponded to one nmol of $\mathrm{H}_{2} \mathrm{O}_{2}$ consumed during the reaction. For peroxidase determination, $3 \mathrm{~mL}$ of reaction mixture contained $0.1 \mathrm{M}$ phosphate buffer ( $\mathrm{pH} 7.0), 0.1 \mathrm{mM}$ guaicol, $0.1 \mathrm{mM} \mathrm{H}_{2} \mathrm{O}_{2}$ and $50 \mu \mathrm{L}$ cell free extract. Reaction was started with the addition of $\mathrm{H}_{2} \mathrm{O}_{2}$ and increase in absorbance at $470 \mathrm{~nm}$ was recorded for $2 \mathrm{~min}$. The activity was calculated using the extinction coefficient value of $22.6 \mathrm{mM}^{-1} \mathrm{~cm}^{-1}$ for guaicol. One unit of enzyme activity was equivalent to $\mu \mathrm{mol}$ of $\mathrm{H}_{2} \mathrm{O}_{2}$ oxidised.
Superoxide dismutase (E.C. 1.15.1.1) activity was assayed by measuring its ability to inhibit the photochemical reduction of NBT (Beauchamp and Fridovich, 1971). The reaction mixture contained a range of enzyme extracts in separate sets and to these added $0.25 \mathrm{~mL}$ of each of $13 \mathrm{mM}$ methionine, $80 \mu \mathrm{M}$ NBT and $0.1 \mathrm{mM}$ EDTA and the total volume of $3.0 \mathrm{~mL}$ was made with buffer in each set. Then $0.25 \mathrm{~mL}$ of $50 \mu \mathrm{M}$ riboflavin was added to each set in the last. The tubes were shaken and placed $30 \mathrm{~cm}$ away from light source ( $4 \times 40 \mathrm{w}$ fluorescent lamps). The reaction was allowed to run for $20 \mathrm{~min}$ and the reaction was stopped by switching off the light. The absorbance was recorded at $560 \mathrm{~nm}$. One unit of enzyme activity represents the amount of enzyme required for $50 \%$ inhibition of NBT reduction at $560 \mathrm{~nm}$.

The activities of glutathione reductase (E.C. 1.6.4.2) and ascorbate peroxidase (E.C. 1.11.1.11) were analysed as described previously (Sheokand et al., 2008). Incubation mixture for GR enzyme assay consisted of $0.1 \mathrm{M}$ phosphate buffer (pH 7.5), $5 \mathrm{mM}$ oxidized glutathione (GSSG), $0.2 \mathrm{mM}$ NADPH and $100 \mu \mathrm{L}$ enzyme extract in a final volume of 1.5 $\mathrm{mL}$. Addition of GSSG, initiated the enzyme reaction. The decrease in absorbance at $340 \mathrm{~nm}$ due to oxidation of NADPH was monitored. The enzyme activity was calculated by using the extinction coefficient value of $6.2 \mathrm{mM}^{-1} \mathrm{~cm}^{-1}$ for NADPH. One unit of enzyme activity was equivalent to one $\mathrm{nmol}$ of NADPH oxidised during the reaction. The composition of APX assay mixture was $50 \mathrm{mM}$ phosphate buffer (pH 7.0), 0.5 $\mathrm{mM}$ sodium ascorbate, $1.0 \mathrm{mM} \mathrm{H} \mathrm{O}_{2}$ and $75 \mu \mathrm{L}$ of enzyme extract in $1.5 \mathrm{~mL}$ final volume. The reaction was initiated by the addition of $\mathrm{H}_{2} \mathrm{O}_{2}$. Reduction in ascorbate concentration was recorded at $290 \mathrm{~nm}$.

The assay mixture for dehydroascorbate reductase (DHAR, E.C. 1.8.5.1) determination contained $100 \mathrm{mM}$ potassium phosphate (pH 7.0), $2.5 \mathrm{mM}$ GSH, $0.2 \mathrm{mM}$ DHA and $0.1 \mathrm{mM}$ EDTA and $50 \mu \mathrm{L}$ enzyme extract in a final volume $1.5 \mathrm{~mL}$. Reaction rates were measured by the increase in absorbance at $265 \mathrm{~nm}$ after adding the enzyme. The calculations were done by using extinction coefficient value of $14 \mathrm{mM}^{-1} \mathrm{~cm}^{-1}$ as described previously (Sheokand et al., 2008). The monodehydroascorbate reductase (MDHAR. E.C. 1.6.5.4) activity was assayed spectrophotometrically (Hossain et al., 1984) by following the decrease in absorbance at $340 \mathrm{~nm}$ due to NADH oxidation. Reaction mixture contained $90 \mathrm{mM}$ potassium phosphate $(\mathrm{pH}$ 7.0), $0.2 \mathrm{mM}$ NADH, $2.5 \mathrm{mM}$ ASA, ASA oxidase (0.25 unit, 
$1 \mu \mathrm{mol}$ ascorbate oxidized $\mathrm{min}^{-1}$ being 1 unit) and $100 \mu \mathrm{L}$ of enzyme extract in a final volume of $1.5 \mathrm{~mL}$ of $25^{\circ} \mathrm{C}$. The reaction was initiated by the addition of ASA oxidase. The calculations were done by using extinction coefficient $6.2 \mathrm{~mm}^{-1} \mathrm{~cm}^{-1}$. One unit of enzyme activity corresponded to one nmol of DHA reduced during the reaction.

Estimation of antioxidant metabolites: Ascorbic acid content was determined with a modification of the procedure of Takahama and Oniki (1992). Fresh leaves $(500 \mathrm{mg})$ were ground in $1.5 \mathrm{~mL}$ of $2 \%(\mathrm{w} / \mathrm{v})$ metaphosphoric acid containing $1 \mathrm{mM}$ EDTA. After centrifugation at $12000 \times g$ for $5 \mathrm{~min}, 500 \mu \mathrm{L}$ of the supernatant was added to $250 \mu \mathrm{L}$ of $10 \%$ (w/v) sodium citrate. $100 \mu \mathrm{L}$ of this mixture and $875 \mu \mathrm{L}$ of $0.2 \mathrm{mM} \mathrm{KH}_{2} \mathrm{PO}_{4}$ buffer $(\mathrm{pH} 7.0)$ and 0.25 units of ascorbate oxidase mixed in $1 \mathrm{~mL}$ cuvette. The absorbance was recorded at $265 \mathrm{~nm}$ until no further decrease was observed (3-4 min). Dehydroascorbate (DHA) was reduced by $2 \mathrm{mM}$ DTT and the ascorbate content calculated by using extinction coefficient $15 \mathrm{mM}^{-1} \mathrm{~cm}^{-1}$.

Total (GSSG + GSH), oxidized and reduced glutathione was determined by adding $1.75 \mathrm{~mL}$ of $0.1 \mathrm{M}$ sodium phosphate buffer (pH 7.5), $0.1 \mathrm{~mL}$ of $2 \mathrm{mM} \mathrm{NADPH}, 0.1 \mathrm{~mL}$ of $5 \mathrm{mM}$ DTNB and $0.2 \mathrm{~mL}$ of TCA extract. Added one unit of standard glutathione reductase (Sigma), mixed well, incubated for 10 min and recorded absorbance at $412 \mathrm{~nm}$ against reagent blank. For estimation of oxidized glutathione, to $1.0 \mathrm{~mL}$ of TCA extract added $0.95 \mathrm{~mL}$ of potassium phosphate buffer $(0.5 \mathrm{M}, \mathrm{pH}$ 7.5) and $50 \mu \mathrm{L}$ of 4 -vinylpyridine (Aldrich). The contents were allowed to stand for $1 \mathrm{~h}$ to remove/degrade GSH. To $0.1 \mathrm{~mL}$ of vinylpyridine treated extract (which was equivalent to $0.05 \mathrm{ml}$ of original TCA extract) added $1.7 \mathrm{~mL}$ of $0.1 \mathrm{M}$ sodium phosphate buffer (pH 7.5), $0.1 \mathrm{~mL}$ of $2 \mathrm{mM}$ NADPH and $0.1 \mathrm{~mL}$ of DTNB. The reaction was started by adding one unit of standard GR enzyme, incubated for 10 min and absorbance was recorded at $412 \mathrm{~nm}$ against reagent blank. Total and oxidized glutathione were calculated by using the equation $y=0.0014 x$ derived from standard curve of reduced glutathione (100 to $1000 \mu \mathrm{M}$ ). The absorbance of standard GSH was recorded at $412 \mathrm{~nm}$ against buffer blank. The concentration of reduced glutathione (GSH) was calculated by subtracting the concentration of GSSG from that of the total glutathione (Smith, 1985).

Cd content in different plants parts and dry matter yield (at maturity): Five hundred $\mathrm{mg}$ of dried samples were digested in $10 \mathrm{~mL}$ of diacid mixture (perchloric acid and nitric acid, 1:9). The volume of digested solution was made to $20 \mathrm{~mL}$ with distilled water and cadmium content was determined by Atomic Absorption Spectrophotometer (PerkinElmer Analyst 100). Dry weight of different plant parts was recorded at maturity.

Statistical analysis: Data was analyzed by using two factorial CRD test.

\section{RESULTS}

Membrane injury and lipid peroxidation: Cadmium stress adversely affected the cell membranes. Cadmium stress of $24 \mathrm{~h}$ resulted in 2.7 fold increase in membrane injury (MI), which further increased to 2.8 fold with $72 \mathrm{~h}$ treatments (Figure $1 \mathrm{~A}$ ). With long term $\mathrm{Cd}$ treatments the increase was 1.8 to 2.2 fold (Figure 1B). Similarly significant augment in malondialdehyde (MDA) content was also found with both short and long term Cd stress. A 47 to $38 \%$ increase was observed at 24 and $72 \mathrm{~h}$ with short term Cd stress (Figure 1C) while with long term $\mathrm{Cd}$ treatments a 69 to $47 \%$ raise in MDA content was detected (Figure 1D). Sodium nitroprusside treatments could partially alleviate the effects of $\mathrm{Cd}$ stress on membrane injury and lipid peroxidation. With short term Cd stress a 44 to $18 \%$ decrease in Ml (\%) and a 26 to $10 \%$ reduction in MDA content was observed after 24 and $72 \mathrm{~h}$ of application while with long term Cd stress, SNP treatments decreased the $\mathrm{Ml}$ (\%) by 39 to $16 \%$ and MDA content by 53 to $45 \%$ after 24 and $72 \mathrm{~h}$ of application (Figure $1 \mathrm{~A}$ - D). The effects of SNP were confirmed by C-PTIO (a scavenger of NO) which reversed the effects of SNP.

Reactive oxygen species (ROS) and $\mathrm{H}_{2} \mathrm{O}_{2}$ content: The total ROS content increased with Cd stress. A 25 to 21 $\%$ increase was detected at 24 and $72 \mathrm{~h}$ with short term $\mathrm{Cd}$ stress (Figure 1E) while with long term $\mathrm{Cd}$ stress promoted a 21 to $24 \%$ increase in ROS content (Figure 1F). A significant increase in $\mathrm{H}_{2} \mathrm{O}_{2}$ content was observed with both long and short term $\mathrm{Cd}$ stress. A two-fold increase in $\mathrm{H}_{2} \mathrm{O}_{2}$ content was found after $24 \mathrm{~h}$ which decreased to $31 \%$ above control levels after $72 \mathrm{~h}$ with short term $\mathrm{Cd}$ stress (Figure $1 \mathrm{G}$ ). The same trend was observed with long term $\mathrm{Cd}$ stress (Figure $1 \mathrm{H}$ ). Sodium nitroprusside treatments decreased the ROS and $\mathrm{H}_{2} \mathrm{O}_{2}$ content with $\mathrm{Cd}$ treatments (Figure $1 \mathrm{E}-\mathrm{H}$ ). Sodium nitroprusside was more effective $24 \mathrm{HAT}$ as compared to $72 \mathrm{HAT}$ in reducing the levels of $\mathrm{ROS}$ and $\mathrm{H}_{2} \mathrm{O}_{2}$. Nitric oxide scavenger c-PTIO reversed the effects of SNP. 


\section{Short term Cd stress}
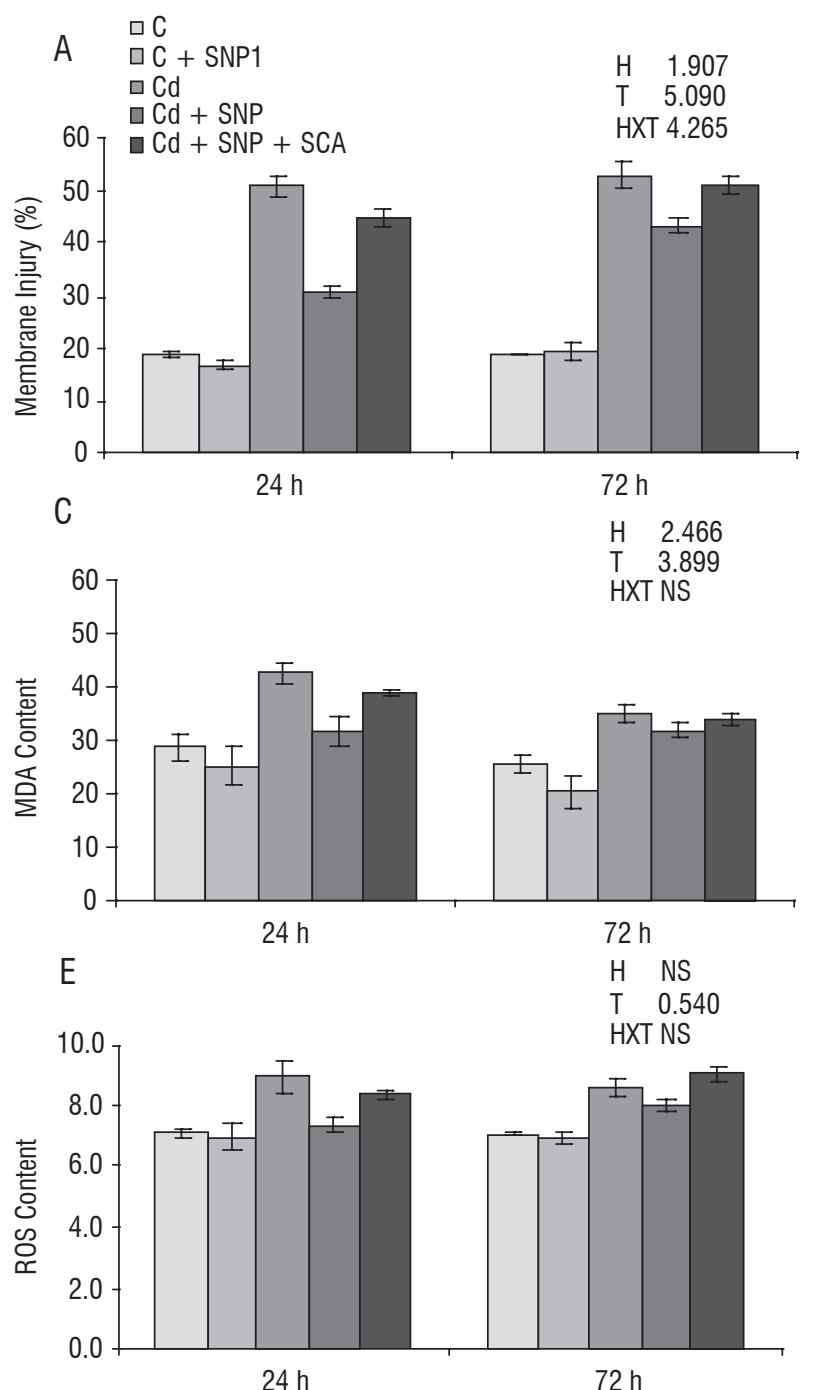

G

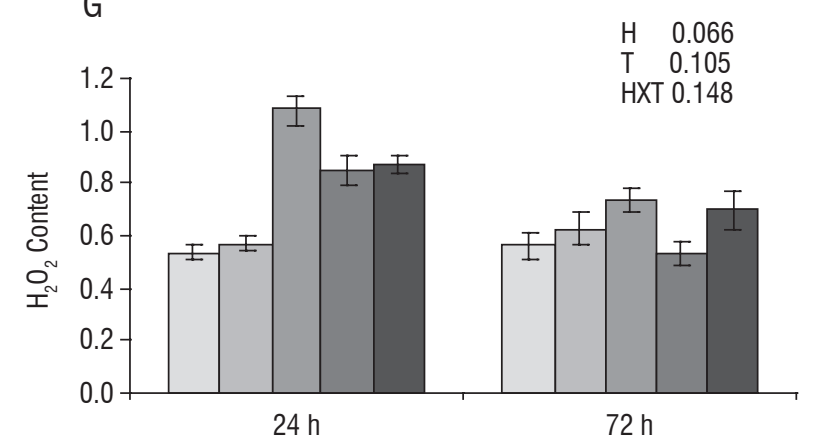

Long term Cd stress
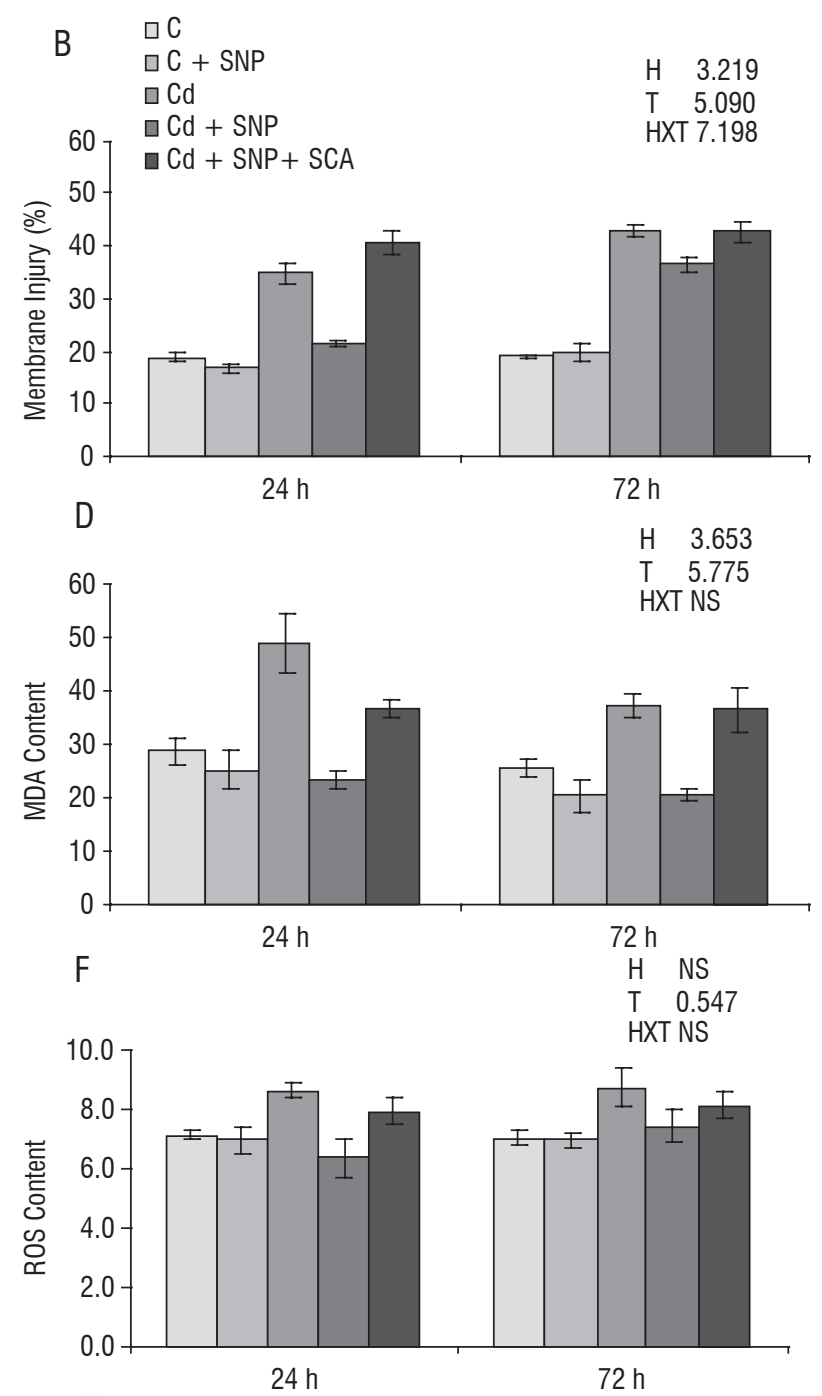

H

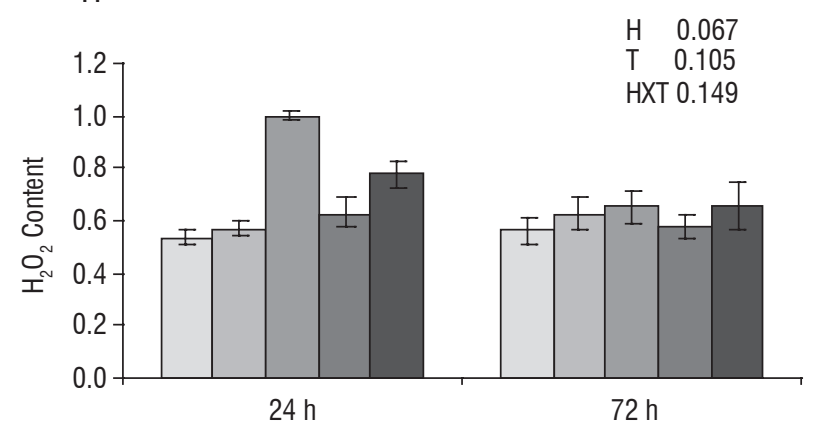

Figure 1. Effect of $\mathrm{Cd}(10 \mathrm{ppm})$ and NO donor (250 $\mu \mathrm{M}$ SNP) on the membrane injury (\%, A - B), MDA content ( $\mu$ mol $\left.\mathrm{g}^{-1} \mathrm{DW}, \mathrm{C}-\mathrm{D}\right)$, total ROS content $\left(\mu \mathrm{mol} \mathrm{g}^{-1}\right.$ DW, E - F) and $\mathrm{H}_{2} \mathrm{O}_{2}$ content ( $\mu \mathrm{mol} \mathrm{g}{ }^{-1} \mathrm{DW}, \mathrm{G}-\mathrm{H}$ ) in chickpea leaves. *The values at right of each figure represent two factorial statistical analysis of data: $\mathrm{H}$, hours after treatment; T, treatment; HXT interaction of both hours and treatments. 


\section{Antioxidant Enzymes}

Catalase, POX and SOD: Cd treatments resulted in an increase in CAT activity. The increase was more pronounced under short term Cd stress. A 58 \% increase in CAT activity was observed with short term $\mathrm{Cd}$ stress while long term $\mathrm{Cd}$ stress showed a less increase (38 to $16 \%$ ) in CAT activity as compared to control levels (Figure $2 \mathrm{~A}$ - B). Sodium nitroprusside treatments further increased the CAT activity in combination with $\mathrm{Cd}$ treatments. A 48 to $17 \%$ increase in CAT activity was detected with short term $\mathrm{Cd}$ stress after 24 and $72 \mathrm{~h}$ and a $17 \%$ increase was found with long term Cd stress (Figure 2
A - B). POX activity was stimulated by 53 to $32 \%$ after 24 and $72 \mathrm{~h}$ under short term $\mathrm{Cd}$ stress (Figure $2 \mathrm{C}$ ). The exposure to long term Cd stress maintained the POX activity 28-24 \% higher than control levels (Figure 2D). Sodium nitroprusside resulted in further increase by $10 \%$ under short term $\mathrm{Cd}$ stress and $34 \%$ stimulation was caused by long term stress $72 \mathrm{~h}$ after application. The SOD activity increased by 13 to $26 \%$ at 24 and $72 \mathrm{~h}$ with short term $\mathrm{Cd}$ stress and was maintained 3 to $16 \%$ higher than control levels under long term $\mathrm{Cd}$ stress (Figure 2 E - F). Sodium nitroprusside treatments further increased SOD activity. The effects of SNP were reversed by scavenger c-PTIO.
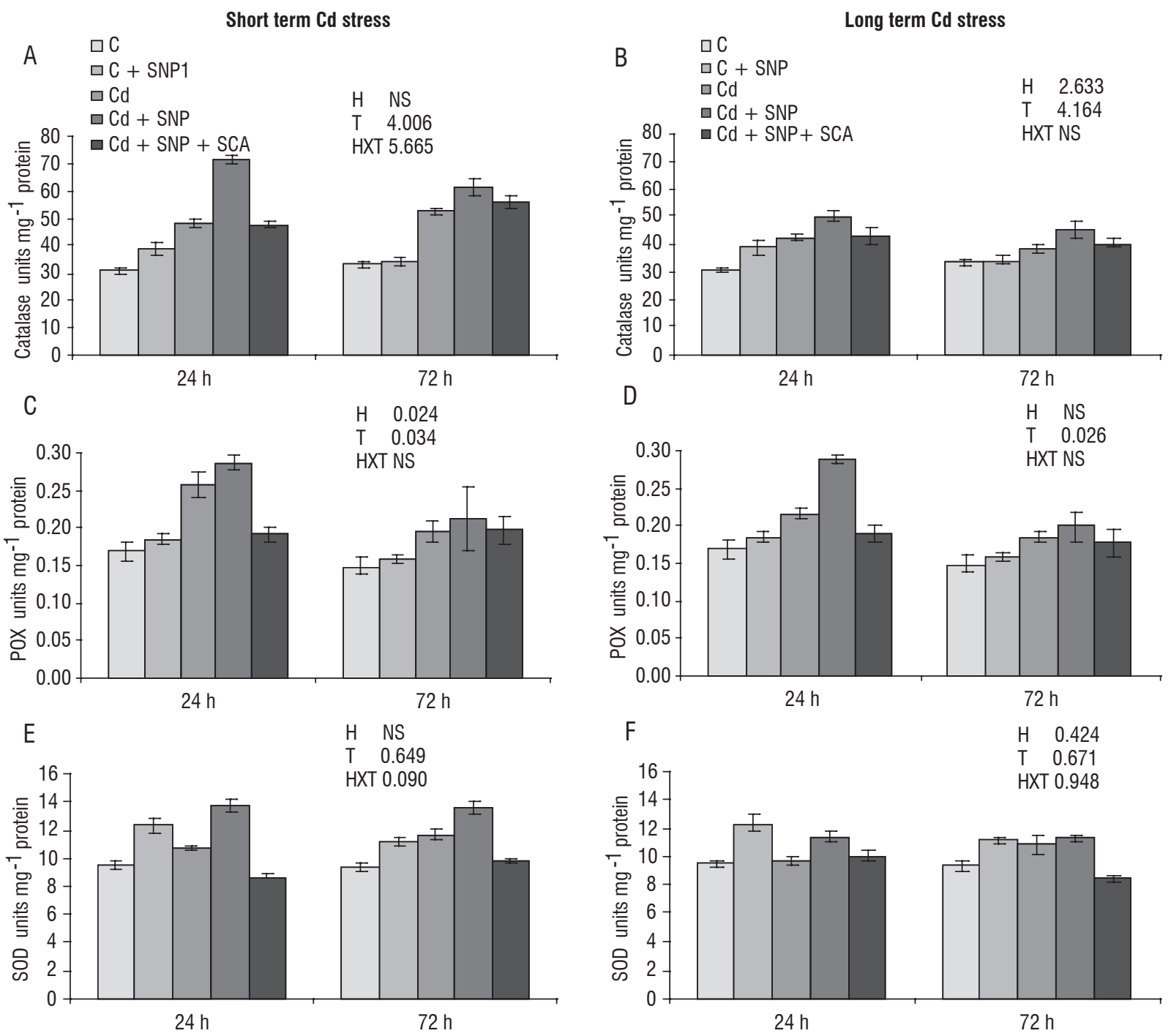

Figure 2. Effect of $\mathrm{Cd}(10 \mathrm{ppm})$ and NO donor (250 $\mu \mathrm{M}$ SNP) on catalase (A - B), peroxidase (C - D) and superoxide dismutase SOD (E - F) activity in chickpea leaves. *The values at right of each figure represent two factorial statistical analysis of data: $\mathrm{H}$, hours after treatment; T, treatment; HXT interaction of both hours and treatments. 
Ascorbate peroxidase, GR, DHAR and MDHAR: A slight increase (9\%) in APX activity was observed $24 \mathrm{~h}$ after $\mathrm{Cd}$ treatment with further stimulation by $35 \%$ after $72 \mathrm{~h}$ of $\mathrm{Cd}$ treatment (Figure 3A). Long term Cd stress had no significant effect on APX activity (Figure 3B). Sodium nitroprusside treatments resulted in an initial increase in APX activity of 38 to $27 \%$ under short term and long term Cd stress after $24 \mathrm{~h}$; however after $72 \mathrm{~h}$ SNP treatment the APX activity was 15 and $12 \%$ above $\mathrm{Cd}$ treated plants. Activity of GR was also stimulated by $\mathrm{Cd}$ stress. Short term $\mathrm{Cd}$ stress promoted 40 to $53 \%$ increase in glutathione reductase activity after 24 and $72 \mathrm{~h}$ (Figure 3C), while with long term Cd stress the increase in GR activity was 25 to $15 \%$ above the control levels (Figure 3D). Sodium nitroprusside was more effective after $24 \mathrm{~h}$ as compared to $72 \mathrm{~h}$ in further increasing GR activity. The DHAR activity exhibited a small initial decline of $13 \%$ after $24 \mathrm{~h}$, a raise by $22 \%$ above control levels after $72 \mathrm{~h}$ with short term $\mathrm{Cd}$ stress and then was maintained between 27 to $35 \%$ with long term $\mathrm{Cd}$ stress (Figure $3 \mathrm{E}-\mathrm{F}$ ). Sodium nitroprusside treatments had a more positive effect after $24 \mathrm{~h}$ of application.
The MDHAR activity was stimulated by $\mathrm{Cd}$ treatments, in a greater extent by long term $\mathrm{Cd}$ stress as compared to short term one (Figure $3 \mathrm{G}-\mathrm{H}$ ). Sodium nitroprusside treatments had a positive effect on MDHAR activity in the control as well as $\mathrm{Cd}$ treated plants. The effects of SNP treatments were confirmed by scavenger $\mathrm{C}-\mathrm{PTIO}$.

Antioxidant metabolites, Ascorbate and Glutathione: Both long and short term $\mathrm{Cd}$ stress resulted in a decrease of the ascorbate redox ratio (ASC/DHA): 58 to $61 \%$ decrease as compared to control plants was observed at 24 and 72 h with short term $\mathrm{Cd}$ stress while long term $\mathrm{Cd}$ stress the decline was 44 to $54 \%$. The addition of sodium nitroprusside improved the ratio. Also, $\mathrm{Cd}$ exposure leads to a reduction of the glutathione redox ratio (GSH/GSSG). A decline of 10 to 25 $\%$ was observed with long and short term $\mathrm{Cd}$ stress. Duration of stress had negative effect on GSH/GSSG ratio. Once again, sodium nitroprusside treatments had a positive outcome and elevated the GSH/GSSG ratio (Table 1). Nitric oxide scavenger reversed the effects of SNP.

Table 1. Effect of $\mathrm{Cd}(10 \mathrm{ppm})$ and NO donor (SNP, $250 \mu \mathrm{M})$ treatments on ascorbate redox ratio (ASC/DHA) and glutathione redox ratio (GSH/GSSG) in chickpea leaves.

\begin{tabular}{|c|c|c|c|c|c|c|c|c|}
\hline \multirow{3}{*}{ Treatments } & \multicolumn{4}{|c|}{ Short term Cd stress } & \multicolumn{4}{|c|}{ Long term Cd stress } \\
\hline & \multicolumn{2}{|c|}{$24 \mathrm{~h}$} & \multicolumn{2}{|c|}{$72 \mathrm{~h}$} & \multicolumn{2}{|c|}{$24 \mathrm{~h}$} & \multicolumn{2}{|c|}{$72 \mathrm{~h}$} \\
\hline & ASC/DHA & GSH/GSSG & ASC/DHA & GSH/GSSG & ASC/DHA & GSH/GSSG & ASC/DHA & GSH/GSSG \\
\hline C & 4.85 & 2.95 & 4.97 & 3.30 & 4.85 & 2.95 & 4.97 & 3.30 \\
\hline$C+S N P$ & 4.60 & 3.63 & 4.80 & 3.34 & 4.60 & 3.63 & 4.80 & 3.34 \\
\hline $\mathrm{Cd}$ & 2.04 & 2.56 & 1.95 & 2.56 & 2.75 & 2.64 & 2.28 & 2.46 \\
\hline $\mathrm{Cd}+\mathrm{SNP}$ & 2.10 & 2.77 & 3.70 & 2.90 & 3.00 & 3.67 & 2.42 & 3.10 \\
\hline $\mathrm{Cd}+\mathrm{SNP}+\mathrm{SCA}$ & 1.32 & 3.00 & 2.43 & 2.49 & 2.68 & 2.79 & 2.21 & 3.08 \\
\hline
\end{tabular}

Cd content of different plant parts: Different parts of plants exhibited augmented cadmium content after both short and long term Cd exposure. An increase by 17, 52, 15, 6, 11 and 24-fold in Cd content comparing to control plants was found in root, nodules, stem, leaves, pod covering and seed, respectively, under long term $\mathrm{Cd}$ stress while these the short term stress resulted in a lesser accumulation of $\mathrm{Cd}$ in different plant parts (Figure 4A). Most of $\mathrm{Cd}$ was retained in roots and nodules of $\mathrm{Cd}$ treated plants. The treatments with nitric oxide donor during short and long term Cd stress promoted improvement and reduced the $\mathrm{Cd}$ content in different plant parts (Figure 4A). 

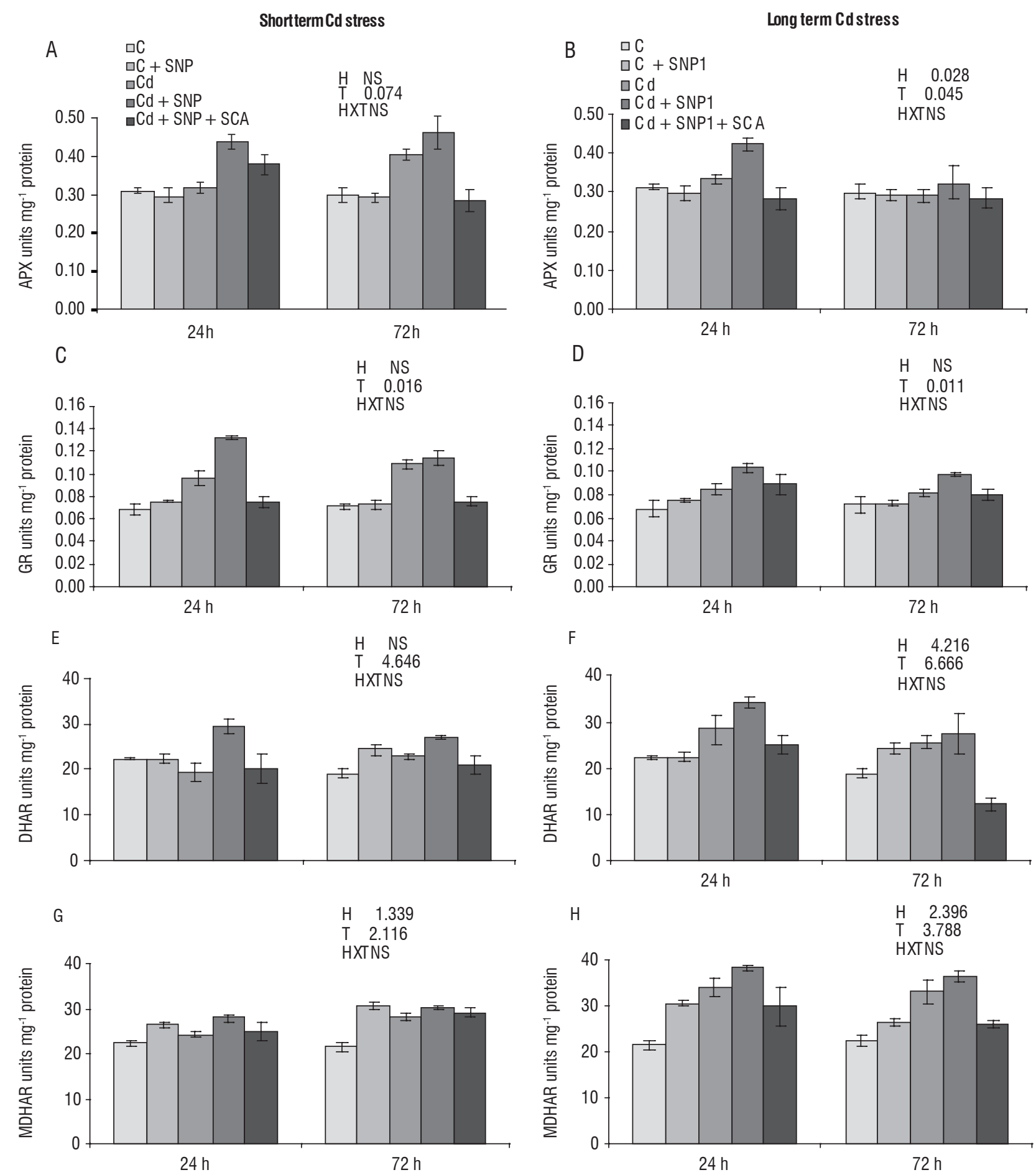

Figure 3. Effect of Cd (10 ppm) and NO donor (250 $\mu \mathrm{M}$ SNP) on APX (A - B), GR (C - D), DHAR (E - F) and MDHAR (G - H) activity in chickpea leaves. *The values at right of each figure represent two factorial statistical analysis of data: $\mathrm{H}$, hours after treatment; $\mathrm{T}$, treatment; HXT interaction of both hours and treatments. 


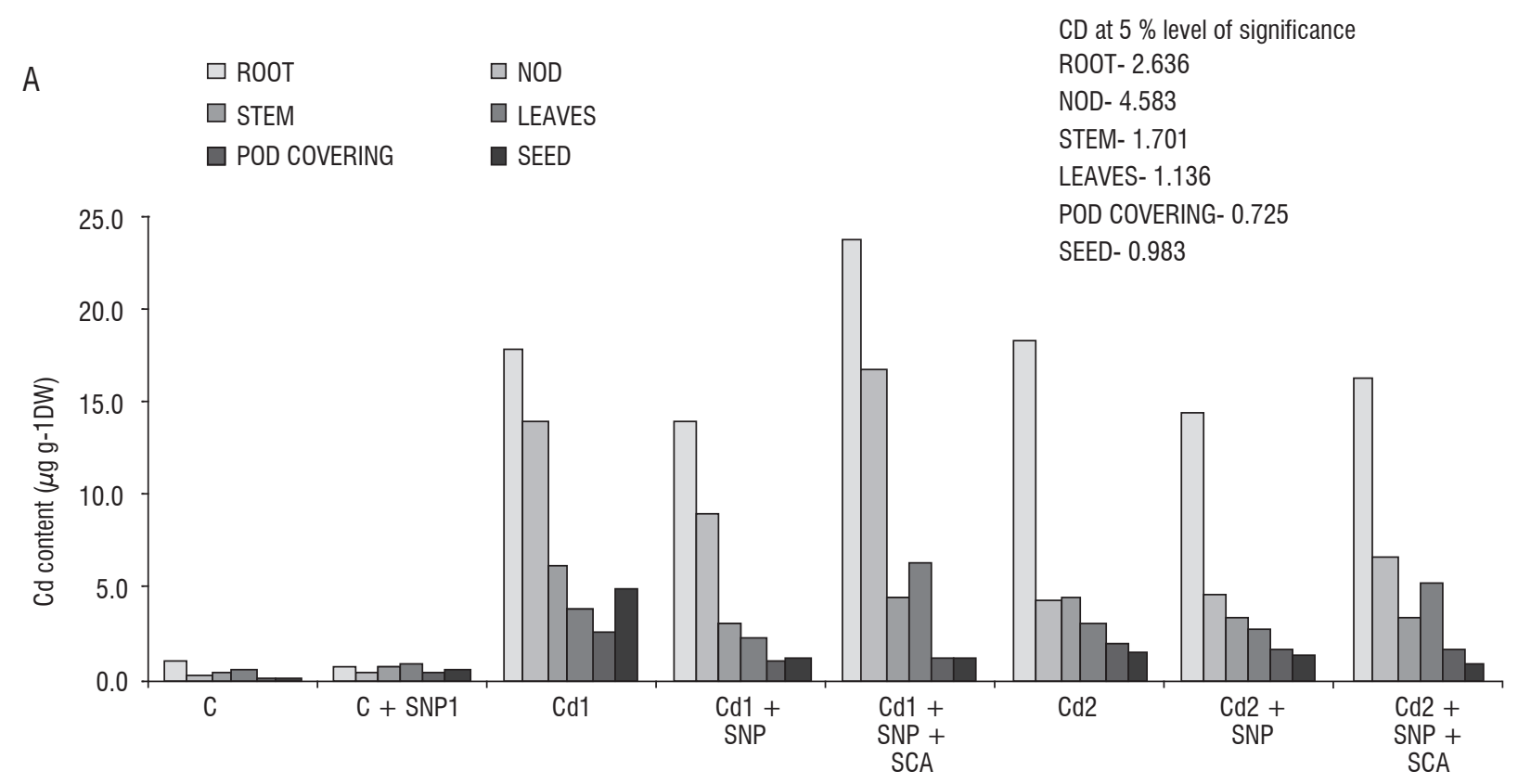

B

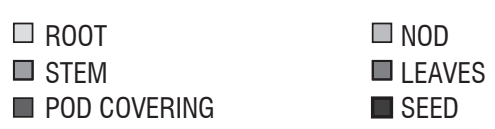

$\mathrm{CD}$ at $5 \%$ level of significance

ROOT- 0.805

NOD- 0.089

STEM- 0.973

LEAVES- 0.643

POD COVERING- 0.131

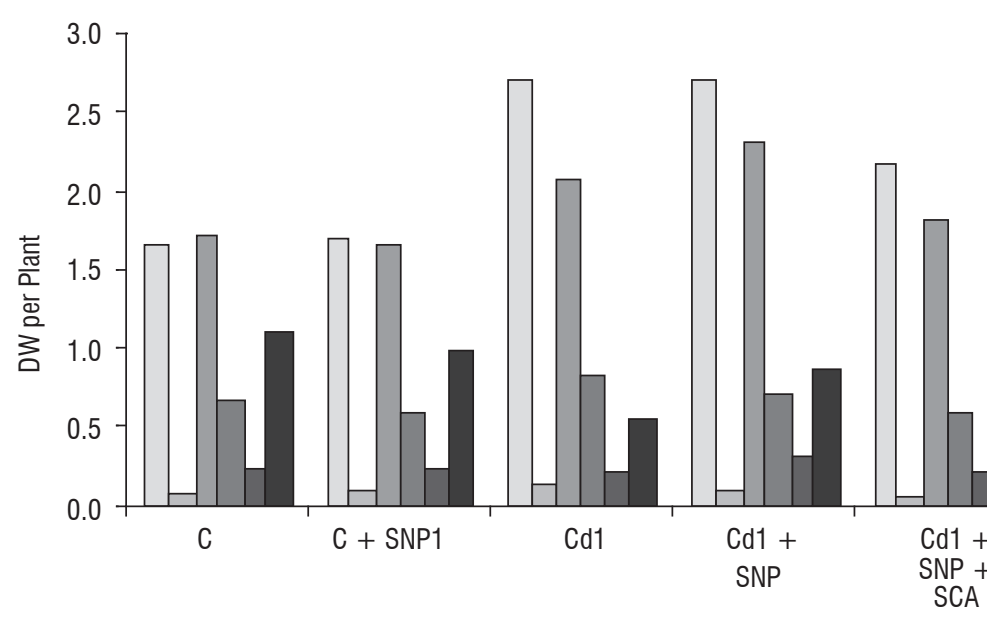

SEED- 0.589

short term Cd stress).

Dry matter yield at maturity: Although cadmium treatments had no adverse effect on root, nodule, stem and seed dry weight, the seed yield decreased significantly. A higher decline in seed yield was observed with long term $\mathrm{Cd}$ stress. About $50 \%$ reduction in yield was found with long term Cd stress against only 12 $\%$ decline under short term $\mathrm{Cd}$ stress (Figure 4B). Nitric oxide donor SNP treatments improved the yield and $50 \%$ increase in seed yield was observed with long and short term Cd stress. 


\section{DISCUSSION}

The present study indicates that both short and long term $\mathrm{Cd}$ exposure resulted in oxidative stress measured in terms of membrane injury (MI), ROS and $\mathrm{H}_{2} \mathrm{O}_{2}$ generation and upregulation of ROS scavenging enzymes.

Cadmum (10 ppm) treatments resulted in membrane damage as evidenced from elevated $\mathrm{Ml}(\%)$ and lipid peroxidation levels (Figure $1 \mathrm{~A}-\mathrm{D}$ ). Lipid peroxidation was measured in terms of MDA content and linked to peroxidation of polyunsaturated fatty acids in the membranes thereby releasing free radicals. A significant increase in MDA production was observed with both short-term and long-term Cd stress (Figure 1C - D). A similar accumulation of peroxides has been reported in response to $\mathrm{Cd}$ after $24 \mathrm{~h}$ treatment in Medicago sativa (Ortega-Villasante et al., 2005). Cadmium induced lipid peroxidation has also been observed in many plant species including pea (Sandalio et al., 2001; Rodriguez-Serrano et al., 2006), Oryza sativa (Choudhary and Panda, 2004), sunflower (Laspina et al., 2005), rice (Hsu and Kao, 2004), Arabidopsis thaliana (Cho and Seo, 2004), wheat roots (Singh et al., 2008), Phaseolus vulgaris (Smeets et al., 2005), and cucumber seedlings (Goncalves et al., 2007).

Due to increased MDA content the membranes became leaky as evidenced by increased electrolyte leakage. A 2.8-fold and 2-fold increase in Ml was detected with short and long term stress, respectively, comparing to control (Figure $1 \mathrm{~A}-\mathrm{B}$ ). Cadmium exposure enhanced lipid peroxidation and altered electrolyte leakage has a negative impact on membrane integrity. Exogenously applied NO donor SNP had a protective effect on $\mathrm{Cd}$ induced membrane damage. The reaction of NO with ROS could prevent the injury to the membranes. It has been reported that the reaction of NO with lipid alcoxyl (LO) and peroxyl (LOO) radicals is rapid and could prevent the propagation of radical medicated lipid peroxidation in a direct fashion (Beligni and Lamattina, 1999). The effect of SNP decreased with the duration of treatments. The effect of NO was confirmed using NO scavenger c-PTIO as it reversed the effect of SNP (Figure 1 $A-B)$. The same tendency was observed for lipid peroxidation (Figure $1 \mathrm{C}$-D). Nitric oxide has also been reported to inhibit ion leakage from plant tissue and protect plants against membrane damage due to lipid peroxidation under photo-oxidative (Beligni and Lamattina, 2002), Cd (Laspina et al., 2005; Singh et al., 2008), drought (Mata and Lamattina, 2001; Wang et al., 2004; Zhao et al., 2008) and salt (Shi et al., 2007; Li et al., 2008; Sheokand et al., 2008) stresses.
Reactive oxygen species content is an important index of oxidative damage. Cadmium is a non-redox metal unable to perform single electron transfer reactions, and does not produce ROS such as the superoxide anion $\left(\mathrm{O}_{2}{ }^{-}\right)$, singlet oxygen, hydrogen peroxide $\left(\mathrm{H}_{2} \mathrm{O}_{2}\right)$ and hydroxyl radical $\left(\mathrm{OH}^{-}\right)$, but generates oxidative stress by interfering with the antioxidant defense system (Choudhary and Panda, 2004; Benavides et al., 2005; Romero-Puertas et al., 2007). An increase in total ROS and $\mathrm{H}_{2} \mathrm{O}_{2}$ content was observed with $\mathrm{Cd}$ stress (Figure $1 \mathrm{E}-\mathrm{H}$ ). An increase in $\mathrm{H}_{2} \mathrm{O}_{2}$ production in response to various heavy metal treatments has been reported earlier (Choudhary and Panda, 2004; Laspina et al., 2005; Rodriguez-Serrano et al., 2006; Mishra et al., 2008). As a consequence of ROS, lipid peroxides are formed which are deleterious to cells. The observed changes in the contents of oxidative markers (MDA, REL, $\mathrm{H}_{2} \mathrm{O}_{2}$ and ROS) with $\mathrm{Cd}$ treatments following short and long term $\mathrm{Cd}$ exposure indicated $\mathrm{Cd}$-induced oxidative stress in chickpea leaves. A substantial increase in $\mathrm{H}_{2} \mathrm{O}_{2}$ content in response to $\mathrm{Cd}$ was also found in wheat roots and it correlated to oxidative stress (Singh et al., 2008).

Antioxidant function of NO may be accomplished by direct removal of ROS (Koprya and Gwozdz, 2003; Hsu and Kao, 2004). This hypothesis was confirmed in our studies. Sodium nitroprusside decreased the total $\mathrm{ROS}$ and $\mathrm{H}_{2} \mathrm{O}_{2}$ content during both short-term and long term $\mathrm{Cd}$ stress (Figure $1 \mathrm{E}-\mathrm{H}$ ). Koprya et al. (2006) reported a decrease in the $\mathrm{O}_{2}{ }^{-}$generation rate in soybean suspension cells. Protective role of NO in reduction of $\mathrm{H}_{2} \mathrm{O}_{2}$ content was observed by Hsu and $\mathrm{Kao}$ (2004) in Oryza sativa and Singh et al. (2008) in wheat roots under Cd stress, water stress in two ecotypes of reed (Zhao et al., 2008), salt stress in cucumber roots (Shi et al., 2007), barley leaves (Li et al., 2008) and ABA induced stress in rice leaves (Hung and Kao, 2003). Application of NO scavenger C-PTIO confirmed the effects of SNP.

In order to scavenge ROS and to avoid oxidative damage, plant possess an antioxidative system comprising of antioxidative enzymes like CAT, POX, SOD, GR, APX, DHAR, MDHAR and non-enzymes like ascorbate, glutathione and $\alpha$-tocopherol. Alteration in the activity of antioxidative enzymes with $\mathrm{Cd}$ stress has been reported by a number of workers (Dixit et al., 2001; Olmos et al., 2003; Hsu and Kao, 2004; Laspina et al., 2005; Rodriguez-Serrano et al., 2006; Goncalves et al., 2007; Singh et al., 2008; Mishra et al., 2008). 
Superoxide dismutase (SOD) is the first enzyme in detoxification process and converts superoxide radicals to $\mathrm{H}_{2} \mathrm{O}_{2}$ at a very fast rate. Enhanced SOD activity was observed with Cd treatment (Figure $2 \mathrm{E}-\mathrm{F}$ ). Increased SOD activity indicates an induction of defense system in response to $\mathrm{Cd}$ stress. Enhanced SOD activity in response to $\mathrm{Cd}$ stress has been detected in other plant species (Kopyra and Gwozdz, 2003; Hsu and Kao, 2004; Laspina et al., 2005; Gomes-Junior et al., 2006; Singh et al., 2008; Mishra et al., 2008).

Sodium nitroprusside had a protective effect on SOD activity (Figure $2 \mathrm{E}-\mathrm{F}$ ) by further increasing the SOD activity thus promoting the conversion of superoxide radicals to hydrogen peroxide, which is an important step in protecting cells. Nitric oxide can readily react with the superoxide anion-radical $\left(\mathrm{O}_{2}{ }^{-}\right)$ as a result a peroxynitrite ion $\left(\mathrm{ONOO}^{-}\right)$is formed. Peroxynitrite is unstable and may protonate as a result of which peroxodioxonitric acid is formed, a source of nitrogen dioxide $\left(\mathrm{NO}_{2}\right)$ and a hydroxyl radical $\left(\mathrm{OH}^{-}\right)$(Wendehenne et al., 2004). Nitric oxide increased SOD activity under $\mathrm{Cd}$ stress has been reported for soybean cells (Koprya et al., 2006), Lupinus luteus roots (Koprya and Gwozdz, 2003) and sunflower (Laspina et al., 2005). The protective effect of SNP on SOD activity was further confirmed by NO scavenger c-PTIO which reversed the effects of SNP.

Due to the action of SOD or by direct formation in biochemical path ways like photorespiration, $\mathrm{H}_{2} \mathrm{O}_{2}$ concentration is expected to increase inside the cell in response to $\mathrm{Cd}$ stress. This has been also observed in our studies also. Although $\mathrm{H}_{2} \mathrm{O}_{2}$ takes part in several important functions in plant cells, control of its build up is essential to prevent oxidative damage to membranes and proteins. The activities of $\mathrm{H}_{2} \mathrm{O}_{2}$ scavenging enzymes POX and CAT increased with $\mathrm{Cd}$ stress and a higher increase was obtained with short term $\mathrm{Cd}$ stress as compared to long trem $\mathrm{Cd}$ stress. Catalase also showed the same tendency by displaying higher activity than control levels (Figure $2 \mathrm{~A}-\mathrm{B}$ ). This increase suggests a compensatory defense mechanism against oxidative stress promoted by toxic metal concentration (Cargnelutti et al., 2006). Furthermore, the combined action of CAT and SOD is critical in mitigating the effects of oxidative stress, since their roles in the cell metabolism are complementary (Benavides et al., 2005). In this sense, it is interesting to note that both SOD and CAT activities increased in Cd treated cucumber and it is widely agreed that plants resist oxidative stress by increasing components of their intrinsic defense system (Benavides et al., 2005). Cadmium induced increase in activities of POX and CAT have been reported by several researches (Dixit et al., 2001; Olmos et al., 2003; Smeets et al., 2005; Rodriguez-Serrano et al., 2006; Singh et al., 2008). Kopyra and Gwozdz (2003) and Laspina et al. (2005) have reported a decline in CAT activity under $\mathrm{Cd}$ stress. Thus, it seems that the differences in activities of antioxidant enzymes in $\mathrm{Cd}$ treated plants are highly dependent on species and experimental model.

It is of note that sodium nitroprusside treatments lead to further elevation of the peroxidase and catalase activities (Figure 2 A-D). Using SNP as NO donor, Beligni and Lamattina (2002) demonstrated a three-fold increase in CAT activity in diquat+SNP treatment as compared to diquat treatment. As shown by means of c-DNA microarray in plants treated with NO the expression of genes of neutral peroxidase and catalase was induced (Huang et al., 2002). Laspina et al. (2005) have reported a decrease in CAT activity with $0.5 \mathrm{mM} \mathrm{Cd}$ and NO treatment completely restored CAT activity by increasing values $21 \%$ over control in sunflower leaves.

To regulate the levels of $\mathrm{H}_{2} \mathrm{O}_{2}$ plants also possess an ascorbate glutathione cycle. Activation of the ascorbate glutathione cycle has been found to be essential in stressed plants to control oxidative damage (Alscher et al., 1997). It is an efficient pathway which detoxifies $\mathrm{H}_{2} \mathrm{O}_{2}$ and is of great importance under heavy metal stress (Tiryakioglu et al., 2006). The cycle includes two low molecular weight antioxidant (ascorbic acid and glutathione) and antioxidant enzymes such as APX, GR, DHAR and MDHAR. Ascorbate peroxidases are the primary $\mathrm{H}_{2} \mathrm{O}_{2}$ scavenging enzymes in chloroplast and cytosol of plant cells. In accordance with their role APX activity increased with $\mathrm{Cd}$ treatments (Figure $3 \mathrm{~A}-\mathrm{B}$ ). Similar to present results, APX activities were found to be increased in rice (Hsu and Kao, 2004), sunflower (Dixit et al., 2001; Laspina et al., 2005) and Ceratophyllum demersum (Mishra et al., 2008) under Cd stress. Contrary to present results, a decline in APX activity under $\mathrm{Cd}$ stress was reported by Zhang et al. (2002) and Gomes-Junior et al. (2006). The reduction in APX activity may be due to GSH depletion and a subsequent reduction in the ascorbate glutathione cycle (Gomes-Junior et al., 2006).

Present results indicate that SNP plays a protective role on APX activity. SNP treatments resulted in an initial increase in APX activity by $29 \%$ and $27 \%$ under short and long term Cd stress of $24 \mathrm{~h}$ and the positive effect of SNP decreased after $72 \mathrm{~h}$ (Figure $3 \mathrm{~A}$ - B). Similarly protective effect of NO on APX activity was observed under Cd stress (Laspina et al., 2005), 
ABA stress (Hung and Kao, 2003) and osmotic stress (Zhao et al., 2008). The effects of SNP were confirmed by the foliar application of NO scavenger with Cd and SNP treatments.

Glutathione reductase, another enzyme of the ascorbate glutathione pathway was activated in leaves of $\mathrm{Cd}$ treated chickpea plants. A 40 to $54 \%$ increase in GR activity, 24 and $72 \mathrm{~h}$ after $\mathrm{Cd}$ treatment was observed (Figure $3 \mathrm{C}$ ). This enzyme reduces GSSG to GSH that is an essential antioxidant and also a substrate for phytochelatin. Cadmium induced increase in GR activity has been reported in pea (Dixit et al., 2001) and Arabidopsis thaliana (Cho and Seo, 2004) and a decrease in activity has been reported in Halianthus annus (Laspina et al., 2005), Oryza sativa (Hsu and Kao, 2004) and Pisum sativum L.(Rodriguez-Serrano et al., 2006). The SNP treatment had a positive effect and further increased the GR activity (Figure $3 \mathrm{C}-\mathrm{D}$ ) and treatments were more effective after $24 \mathrm{~h}$ as compared to $72 \mathrm{~h}$. A small positive effect of NO on GR activity in $\mathrm{Cd}$ treated leaves has been reported in sunflower leaves (Laspina et al., 2005). Sodium nitroprusside treatment brought down the GR activity to control level under Cd stress in wheat roots (Singh et al., 2008).

The enzymes DHAR and MDHAR also play a major role in detoxification of ROS in the ascorbate glutathione pathway. Both DHAR and MDHAR activities were induced with $\mathrm{Cd}$ treatments (Figure $3 \mathrm{E}-\mathrm{F}, \mathrm{G}-\mathrm{H}$ ). The increase in MDHAR activity under $\mathrm{Cd}$ treatments have been reported by Markovska et al. (2009) in $B$. juncea and by Romero-Puertas et al. (2007) in Pisum sativum plants. Decrease in DHAR activity under Cd treatment $(10 \mu \mathrm{M})$ in Ceratophyllum demersum has been reported by Arvind and Prasad (2005). Nitric oxide donor SNP had a positive effect on both DHAR and MDHAR activities. Higher activities of DHAR and MDHAR are important for keeping higher substrate concentration for APX. There are no earlier reports on the effect of NO on MDHAR activity under $\mathrm{Cd}$ stress in the literature.

Ascorbic acid is a primary as well as secondary antioxidant found in plants and has diverse physiological roles. A decline in ascorbate redox ratio (ASC/DHA) and glutathione redox ratio (GSH/GSSG) was observed with Cd treatment (Table 1). The ratios of GSH/GSSG and ASC/DHA are considered as markers of oxidative stress. SNP treatments had a positive effect on both ASC/DHA and GSH/GSSG ratio indicating a compensatory mechanism in which there is increased recycling of glutathione to keep it in its active reduced form. The fact that NO maintains the ASC and GSH in reduced state under
Cd stress might be explained by increased activities of GR, APX, DHAR and MDHAR enzymes. This results in the improved capacity of the antioxidant system to scavenge $\mathrm{H}_{2} \mathrm{O}_{2}$. Decrease in glutathione content with $\mathrm{Cd}$ stress has been reported in sunflower leaves (Laspina et al., 2005) and in pea (Dixit et al., 2001). However, an increase also has been reported under Cd stress (Tiryakioglu et al., 2006). Laspina et al. (2005) have reported a positive effect of NO on GSH content in Cd treated sunflower leaves. Nitric oxide could be acting simply as an antioxidant (Beligni and Lamattina, 1999) or might be playing a role in the elevation of GSH levels either by increased biosynthesis of this metabolite or through an increased supply of cysteine the limiting substrate (Li et al., 1999).

Cadmium has been shown to cause many morphological, physiological, biochemical and structural changes in plants, such as growth inhibition, water imbalance and inhibition of seed germination (Benavides et al., 2005). Cadmium treatments resulted in significant accumulation of $\mathrm{Cd}$ in different plant parts(Figure 4A). Most of the $\mathrm{Cd}$ is retained in roots and nodules of $\mathrm{Cd}$ treated plants. A higher accumulation of $\mathrm{Cd}$ in roots as compared to shoot has been reported by many workers (Sandalio et al., 2001; Dixit et al., 2001; Goncalves et al., 2007; Abdel-Latif, 2008).

Due to high accumulation of $\mathrm{Cd}$ the yield of plant was also affected. In our results, Cd treatments had no adverse effect on root, nodule, stem dry weight, however seed yield decreased significantly. A higher decline in seed yield was found with long term $\mathrm{Cd}$ stress as compared to short term $\mathrm{Cd}$ stress (Figure 4B). Cadmium induced decrease in plant biomass has been reported by many workers (Cheng and Huang, 2006; Goncalves et al., 2007; Malekzadeh et al., 2007; Abdel-Latif, 2008 and Farooqi et al., 2009). Goncalves et al. (2007) observed a significant decrease in root length and dry weight; however the effect was more prominent on root length than on dry weight. Notably SNP showed a positive effect by decreasing $\mathrm{Cd}$ accumulation and increasing seed yield in $\mathrm{Cd}$ treated plants (Figure $4 \mathrm{~A}-\mathrm{B}$ ). No long term experiments on the effect of $\mathrm{Cd}$ and SNP on $\mathrm{Cd}$ accumulation and seed yield have been reported earlier.

\section{CONCLUSIONS}

Cadmium stress adversely affected the membranes, oxidative metabolism and plant yield. Short term stress was more deleterious in terms of membrane injury and oxidative 
metabolism and long term stress was more deleterious in terms of plant yield and Cd accumulation. SNP $(250 \mu \mathrm{M})$ was effective in decreasing $\mathrm{MI}(\%), \mathrm{MDA}, \mathrm{H}_{2} \mathrm{O}_{2}$ and $\mathrm{ROS}$ content, increasing the activity of antioxidant enzymes like SOD, CAT, POX, APX, DHAR, MDHAR and the GSH/GSSG and ASC/DHA ratio under $\mathrm{Cd}$ stress. The positive effect of SNP on plant biomass and seed yield under $\mathrm{Cd}$ stress could be attributed to the fact that NO acts as a growth regulator.

\section{REFERENCES}

Abdel-Latif A (2008) Cadmium induced changes in pigment content, ion uptake, proline content and phosphoenolpyruvate carboxylase activity in Triticum aestivum seedlings. Aust. J. Basic App. Sci. 2:57-62.

Able AJ, Sutherland MW, Guest DI (2003) Production of reactive oxygen species during non-specific elicitation, non-host resistance and field resistance expression in cultured tobacco cells. Func. Plant Biol. 30:91-99.

Alscher RG, Donahue JL, Cramer CL (1997) Reactive oxygen species and antioxidants: relationships in green cells. Physiol. Plant. 100:224-233.

Arvind P, Prasad MNV (2005) Modulation of cadmium-induced oxidative stress in Ceratophyllum demersum by zinc involves ascorbate-glutathione cycle and glutathione metabolism. Plant Physiol. Biochem. 43:107-116.

Beauchamp C, Fridovich I (1971) Superoxide dismutase: Improved assays and an assay applicable to acrylamide gels. Anal. Biochem. 44:276-287.

Beligni MV, Lamattina L (1999) Is nitric oxide toxic or protective? Trends Plant Sci. 4:299-300.

Beligni MV, Lamattina L (2002) Nitric oxide interferes with plant photooxidative stress by detoxifying reactive oxygen species. Plant Cell Environ. 25:737-748.

Beligni MV, Lamattina L (2000) Nitric oxide stimulates seed germination and de-etiolation and inhibits hypocotyl elongation, three-light inducible responses in plants. Planta 210:215-221.

Benavides MP, Gallego SM, Tomaro ML (2005) Cadmium toxicity in plants. Braz. J. Plant Physiol. 17:21-34.

Cargnelutti D, Tabaldi LA, Spanevello RM, Jucoski GO, Battisti V, Redin M, Linares CEB, Dressler VL, Flores EMM, Nicoloso FT, Morsch VM, Schetinger MRC (2006) Mercury toxicity induces oxidative stress in growing cucumber seedlings. Chemosphere 65:999-1006.

Cheng S-F, Huang C-Y (2006) Influence of cadmium on growth of root vegetable and accumulation of cadmium in the edible root. Int. J. App. Sci. Eng. 3:243-252.

Cho U, Seo N (2004) Oxidative stress in Arabidopsis thaliana exposed to cadmium is due to hydrogen peroxide accumulation. Plant Sci. 168:113-120.

Choudhary S, Panda SK (2004) Role of salicylic in regulating cadmium induced oxidative stress in Oryza sativa roots. Bulg. J. Plant Physiol 30:95-110.

Desikan R, Cheung M-K, Bright J, Henson D, Hancock JT, Neill SJ (2004) $\mathrm{ABA}$, hydrogen peroxide and nitric oxide signaling in stomatal guard cells. J. Exp. Bot. 55:205-212.

Dixit V, Pandey V, Shyam R (2001) Differential antioxidative responses to cadmium in roots and leaves of pea (Pisum sativum L. cv. Azad). J. Exp. Bot. 52:1101-1109.

Faroogi ZR, Iqbal MZ, Kabir M, Shafiq M (2009) Toxic effects of lead and cadmium on germination and seedling growth of Albizia lebbeck (L.) bength. Pakistan J. Bot. 41:27-33.

Gomes-Júnior RA, Moldes CA, Delite FS, Pompeu GB, Gratão PL, Mazzafera P, Lea PJ, Azevedo RA (2006) Antioxidant metabolism of coffee cell suspension cultures in response to cadmium. Chemosphere 65:1330-1337.
Goncalves JF, Becker AG, Cargnelutti D, Tabaldi LA, Pereira LB, Battisti V, Spanevello R, Morch VM, Nicoloso FT, Schetinger MRC (2007) Cadmium toxicity causes oxidative stress and induces response to the antioxidant system in cucumber seedlings. Braz. J. Plant Physiol. 19:24-26.

He Y, Tang R-H, Hao Y, Stevens RD, Cook CW, Ahn SM, Jing L, Yang Z, Chen L, Guo F, Fiorani F, Jackson RB, Crawford NM, Pei Z-M (2004) Nitric oxide represses the Arabidopsis floral transition. Science 305:1968-1971.

Hossain MA, Nakano Y, Asada K (1984) Mono-dehydroascorbate reductase in spinach chloroplast and its participation in regeneration of ascorbate for scavenging hydrogen peroxide. Plant Cell Physiol. 11:351-358.

Hsu YT, Kao CH (2004) Cadmium toxicity is reduced by nitric oxide in rice leaves. Plant Growth Regul. 42:227-238.

Hu X, Neill SJ, Tang Z, Cai W (2005) Nitric oxide mediates gravitropic bending in soybean roots. Plant Physiol. 137:663-670.

Huang X, Rad U, Durner J (2002) Nitric oxide induces transcriptional activation of nitric oxide-tolerant alternative oxidase in Arabidopsis suspension cells. Planta 215:914-923.

Hung KT, Kao CH (2003) Nitric oxide counteracts the senescence of rice leaves induced by abscisic acid. J. Plant Physiol. 160:871-879.

Kopyra M, Gwozdz EA (2003) Nitric oxide stimulates seed germination and counteracts the inhibitory effect of heavy metals and salinity on root growth of Lupinus luteus. Plant Physiol. Biochem. 41:1011-1017.

Kopyra M, Stachon-Wilk M, Gwozdz EA (2006) Effect of exogenous nitric oxide on the antioxidant capacity of cadmium-treated soybean cell suspension. Acta. Physiol. Plant. 28:525-536.

Laspina NV, Groppa MD, Tomaro ML, Benavides MP (2005) Nitric oxide protects sunflower leaves against Cd-induced oxidative stress. Plant Sci. 169:323-330.

Li H, Marshall ZM, Whorton AR (1999) Stimulation of cysteine nitric oxide: regulation of endothelial cell glutathione levels. Plant Physiol. Cell Physiol. 276:803-811.

Li Q-Y, Niu H-B, Yin J, Wang M-B, Shao H-B, Deng D-Z, Chen X-X, Ren J-P, Li $Y-C$ (2008) Protective role of nitric oxide against oxidative- stress induced by salt stress in barley (Hordeum vulgare L.) Colloids and Surfaces B:Biointerfaces 65:220-225.

Malekzadeh P, Khara J, Farshian S (2007) Cadmium toxicity in maize seedlings: Changes in antioxidant enzyme activities and root growth. Pakistan J. Biol. Sci. 10:127-131.

Markovska Y K, Gorinova NI, Nedkovska MP, Miteva1 KM (2009) Cadmiuminduced oxidative damage and antioxidant responses in Brassica juncea plants. Biol. Plant. 53:151-154.

Mata CG, Lamattina L (2001) Nitric oxide induces stomatal closure and enhances the adaptive plant responses against drought stress. Plant Physiol. 126:1196-1204.

Milone MT, Sgherri C, Clijters H, Navari-Izzo F (2003) Antioxidative responses of wheat treated with realistic concentration of cadmium. Environ. Exp. Bot. 50:265-273.

Mishra S, Srivastava S, Tripathi RD, Dwivedi S, Shukla MK (2008) Response of antioxidant enzymes in coontail (Ceratophyllum demersum L.) plants under cadmium stress. Environ. Toxicol. 23:294-301.

Olmos E, Martinez-Solano JR, Piqueras A, Hellin E (2003) Early steps in the oxidative burst induced by cadmium in cultured tobacco cell (BY-2 line). J. Exp. Bot. 54: 291-301.

Ortega-Villasante C, Rellan-Alvarez R, Del Campo FF, Carpena-Ruiz RO, Hernández LE (2005) Cellular damage induced by cadmium and mercury in Medicago sativa. J. Exp. Bot. 56:2239-2251.

Rodriguez-Serrano M, Romero-Puertas MC, Zabalza A, Carpas FJ, Comez M, Del-Rio LA, Sandalio LM (2006) Cadmium effect on oxidative metabolism of pea (Pisum sativum L.) roots. Imaging of reactive oxygen species and nitric oxide accumulation in vivo. Plant Cell Environ. 29:1532-1544. 
Romero-Puertas MC, Corpas FJ, Rodríguez-Serrano M, Gómez M, del Río LA, Sandalio LM (2007) Differential expression and regulation of antioxidative enzymes by cadmium in pea plants. J. Plant Physiol. 164:1346-1357.

Romero-Puertas MC, Rodríguez -Serrano M, Carpas FJ, Gómez M, del Río LA, Sandalio LM (2004) Cadmium-induced subcellular accumulation of $\mathrm{O}_{2}^{-}$and $\mathrm{H}_{2} \mathrm{O}_{2}$ in pea leaves. Plant Cell Environ. 27:1122-1134.

Sandalio LM, Dalurzo HC, Gomez M, Romero-Puetras MC, del Río LA (2001) Cadmium-induced changes in the growth and oxidative metabolism of pea plants. J. Exp. Bot. 52:2115-2126.

Sanita di Toppi L, Gabbrielli R (1999) Responses to cadmium in higher plants. Environ. Exp. Bot. 41:105-130.

Sheokand S, Kumari A, Sawhney V (2008) Effect of nitric oxide and putrescine on antioxidative responses under $\mathrm{NaCl}$ stress in chickpea plants. Physiol. Mol. Biol. Plant. 14: 355-362.

Shi Q, Ding F, Wang X, Wei M (2007) Exogenous nitric oxide protect cucumber roots against oxidative stress induced by salt stress. Plant Physiol. Biochem. 45:542-550.

Singh HP, Batish DR, Kaur G, Arora K, Kohli RK (2008) Nitric oxide (as Sodium nitroprusside) supplementation ameliorates $\mathrm{Cd}$ toxicity in hydroponically grown wheat roots. Environ. Exp. Bot. 63:158-167.

Sinha AK (1972) Colorimetric assay of catalase. Anal. Biochem. 47:389-395.

Smeets K, Cuypers A, Lambrechts A, Semane B, Hoet P, VanLaera A, Vangronsveld $J(2005)$ Induction of oxidative stress and antioxidative mechanisms in Phaseolus vulgaris after Cd application. Plant Physiol. Biochem. 43:437-444.

Smith IK (1985) Stimulation of glutathione synthesis in photorespiring plants by catalase inhibitors. Plant Physiol. 79:1044-1047.

Takahana U, Okini T (1992) Regulation of peroxidase-dependent oxidation of phenolic in the apoplast of spinach leaves by ascorbate. Plant Cell Physiol. 33:379-387.
Tiryakioglu M, Eker S, Ozkutlu F, Husted S, Cakmak I (2006) Antioxidant defense system and cadmium uptake in barley genotypes differing in cadmium tolerance. J. Trace Elem. Med. Biol. 20:181-189.

Wang XY, Shen WB, Xu LL (2004) Exogenous nitric oxide alleviates osmotic stress induced lipid peroxidation in wheat seedling leaves. Zhi Wu Sheng Li Yu Fen Zi Sheng Wu Xue Xue Bao. 30: 195-200.

Wang YS, Yang ZM (2005) Nitric oxide reduces aluminium toxicity by preventing oxidative stress in the roots of Cassia tora L. Plant Cell Physiol. 46:1915-1923.

Wendehenne D, Durner J, Klessing DF (2004) Nitric oxide: a new player in plant signaling and defence responses. Curr. Opin. Plant Biol. 7:449-455.

Wilson D0, Reisenauer HM (1963) Cobalt requirements of symbiotically grown alfalfa. Plant Soil 19:364-373

Zhang F, Shi W, Jin Z, Shen Z (2002) Response of antioxidative enzymes in cucumber chloroplasts to cadmium toxicity. J. Plant Nutr. 26:1779-1688.

Zhang YY, Wang LL, Liu YL, Zhang Q, Wei QP, Zhang WH (2006) Nitric oxide enhances salt tolerance in maize seedlings through increasing activities of proton-pump and $\mathrm{Na}^{+} / \mathrm{H}^{+}$antiport in the tonoplast. Planta 224:545-555

Zhao L, He J, Wang X, Zhang L (2008) Nitric oxide protects against polyethylene glycol-induced oxidative damage in two ecotypes of reed suspension cultures. J. Plant Physiol. 165:182-191.

Zhou B, Guo Z, Xing J, Huang B (2005) Nitric oxide is involved in abscisic acid-induced antioxidant activities in Stylosanthes guianensis. J. Exp. Bot. 56:3223-3228

Zottini M, Formentin E, Scattolin M, Carimi F, LO Schiavo FL, Terzi M (2002) Nitric oxide affects plant mitochondrial functionality in vivo. FEBS Lett. 515:75-78. 